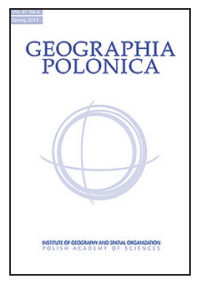

\title{
POPULATION AGE STRUCTURE TRANSFORMATION IN THE CAPITALS OF THE VISEGRAD GROUP COUNTRIES
}

\section{Jana Ondačková ${ }^{1}$ • Marcela Káčerová ${ }^{2}$ • Jozef Mládek ${ }^{3}$ • Dagmar Popjaková $^{3}$ • Michal Vančura ${ }^{3}$}

\author{
${ }^{1}$ Department of Remote Sensing of the Earth and Geoinformatics \\ Soil Science and Conservation Research Institute \\ Trenčianska 55, SK-821 09 Bratislava: Slovakia \\ e-mail: j.ondackova@vupop.sk \\ ${ }^{2}$ Faculty of Natural Sciences, Department of Human Geography and Demography \\ Comenius University in Bratislava \\ Mlynská dolina, Ilkovičova 6, SK-84215 Bratislava: Slovakia \\ e-mail: marcela.kacerova@uniba.sk \\ ${ }^{3}$ Faculty of Education, Department of Geography \\ University of South Bohemia \\ Jeronýmova 10, CZ-37115 České Budějovice: Czechia \\ e-mails: mladek@pf.jcu.cz・dpopjakova@pf.jcu.cz・vancura@pf.jcu.cz
}

\begin{abstract}
The study provides a compact view of population ageing in the capitals of the Visegrad Group (V4). The transformation of the age structure of urban populations is quantified within the context of the V4 countries Czechia, Hungary, Poland and Slovakia. This assessment of the age structure transformation in the V4 capitals between 1980 and 2013 was carried out using Webb's chart and hexagonal diagram methods. The evaluation of the demographic ageing of the urban populations brings substantial knowledge of the immanent differences of the capitals. The similarities between Prague, Budapest and Warsaw and the specific development of Bratislava, was revealed.
\end{abstract}

\section{Key words}

age structure - population ageing $\bullet$ capitals of the Visegrad Group countries

\section{Introduction}

One of the general regularities of the population development in most countries of the world involves the change of the population age structure, known as population ageing (less frequent is the process of population rejuvenation). From the demographic viewpoint, these changes involve an increase in the number or proportion of the population in higher 
age categories (top-down population ageing). The changes also involve a reduction in the number and proportion of the younger age categories (bottom-up ageing). This seemingly simple assessment of the younger and older age categories of the population is complicated by their mutual relationship as well as the relationship to the other age categories of the population under assessment.

Current population development is undergoing many changes. Population aging is one of the integral features. The earlier onset of this process was recorded in the countries of Western and Northern Europe. However, special attention must be paid to the countries of Central and Eastern Europe, where significant changes in the political, economic and social life after the democratic changes in 1989 meant that the aging of the population in this area takes place with an interval of approximately 20-30 years, but faster and more intensely.

Demographic analysis mostly deals with this issue on a national level (Bijak et al. 2007; Długosz 2007; Arltová \& Langhamrová 2010; Bucher 2014; Káčerová \& Ondačková 2015), which to some extent depends on the availability of data. The regional level is usually characterized by analyses of NUTS3 or NUTS4 units (Kurek 2008; Mládek \& Káčerová 2008; Bucher 2012), or the differences between urban and rural areas as a whole (Szymańska et al. 2009; Mládek \& Čupel’ová 2010).

Available studies identify as the oldest, small rural communities suffering from internal out-migration, and the other large cities with more complex changes in demographic behaviour, for example single-person households, low marriage rate, high extramarital birth rate. Analyses at the city level in the area of Eastern Europe focused more on urban development (Musil 1997; Ruoppila 2004; Kovács 2005; Mykhnenko \& Turok 2007) and social change (Górczyńska 2014), and to a lesser extent on demographic behaviour (Divinský 2001; Krejčí et al. 2011). These papers show that in recent years large cities in Central and Eastern Europe have experienced a significant transformation of their functional or residential character. These changes have also determined the new demographic behaviour of urban populations in terms of reproductive and family behaviour, but also the educational, ethnic, and especially age structure.

The urban population is ageing more dynamically than the rural population (Enyedi 2009; Olivieri et al. 2015). The United Nations Population Fund estimates that by 2020, over $50 \%$ of the people aged 60 years or older will live in an urban environment. Global population ageing alongside rapid urbanization will mean: (a) Most of us, and more of us than ever before, will grow old in towns and cities, (b) Of the people living in towns and cities, more of us than ever before will be older. From 2001 to 2011, the number of older people increased by $23.8 \%$ in OECD metropolitan areas, while it increased by $18.2 \%$ in nonmetropolitan areas (OECD 2015).

The aim of this study is to provide a comparative analysis of population aging in the capitals of the Visegrad Group countries (V4) from the mid-1980s to the present day. As shown by previous analyses of the population aging of the V4 countries (Káčerová \& Ondačková 2015), two pairs of populations with similar demographic trends were identified in terms of long-term population development: the more liberal Czechia and Hungary - that had an earlier onset of population ageing - and the more conservative Slovakia and Poland with a stronger link to the traditional family and a younger age structure. This suggests that the development of the largest urban populations in these countries should be similar, which was the basic hypothesis of the goal of our study. Undisputed, however, is the urban population factor as shown above, which suggests that the aging of the urban population is proceeding more dynamically, irrespective of the country's demographic development. The urban population is subject to trends and changes faster (see text below). The specificity of the environment is given by higher education, awareness.

V4 is the alliance of three post-socialist countries of Central Europe (Czechoslova- 
kia, Hungary and Poland) which was established in 1991, and whose aim was close cooperation among its member countries, in particular their common approach to European integration processes. After the split of Czechoslovakia in 1993 into two separate states (Czechia and Slovakia) the alliance was named V4. The V4 countries represent a geographical area that in macro-regional terms is most frequently classified as Central or Eastern Europe (Morris 1972; De Blij \& Muller 1988; Bičík et al. 2010; UNDATA 2014).

The four V4 countries have a combined population of 64.3 million inhabitants, with their capital cities together numbering 5.1 million inhabitants. Bratislava, the capital city of Slovakia, is the smallest city, with 417,000 inhabitants, followed by Prague the capital city of Czechia, with 1.2 million inhabitants. Budapest and Warsaw, the capitals cities of Hungary and Poland, both reported 1.7 million inhabitants. Bratislava has the smallest area at $368 \mathrm{~km}^{2}$, Prague $496 \mathrm{~km}^{2}$, Warsaw covers $517 \mathrm{~km}^{2}$ while Budapest $525 \mathrm{~km}^{2}$. Selected indicators are used to quantify changes in population age structures and processes in the context of societal development and to identify convergent and divergent trends of the populations. The period under review varies due to the availability of comparable data from the 1980s and 1990s to the present.

\section{Methodology}

The analyses of the processes of ageing are based on the population databases provided by national statistical institutions. All 4 capital cities were judged as internal urban structures, i.e., without external agglomerations (agglomerated bodies).

The basic methodological processes represented comparison of chosen demographic characteristics of the age structures. Comparisons were also used in the organized statistical tables and in the chosen graphic techniques.

In an effort to synthetically uncover and explain the transforming age structures of the affected urban populations over the analysed period, the study uses several methodologies.

The complexity of the age structure is shown by the hexagonal diagram enabling the study of spatial and temporal differences in the aging population (SonIs 1981). The essence of this method lies in the characteristics of each capital city by the relative representation of three main age categories of the population (0-14 years, 15-64 years and 65 years and over) and their changes, in our case, according to different time periods. The result of the comparison is a vector $\left(\mathrm{D}_{0-14}, \mathrm{D}_{15-64}, \mathrm{D}_{65}\right)$ characterized by a triad of values providing information on the relative aging of the population. When $\mathrm{D}_{0-14}<0$, it is bottom-up aging, whereas $D_{65+}>0$, refers to top-down ageing.

A synthetic view of the dynamics of the population is provided by a Webb graph. In this graph, each city is assigned a crude rate of natural increase and a crude rate of net migration movement. The combination of positive and negative crude rates creates eight octants. The total population movement of octants $A, B, E$ and $F$ is primarily due to the natural movement of the population. Conversely, the overall movement of octants $C$, $D, G$ and $H$ is decided by migratory population movements.

The analysis of population processes is based on the traditional crude rate. The crude rate of the three analysed processes of population dynamics (fertility, mortality and migration) is subject to the influence of the age structure. Their explanatory ability is approximate. However, due to the unavailability of a comprehensive time series of more specific indicators of major cities (the rates by age required to construct total fertility rate and life expectancy), we have been forced to work with these fundamental indicators.

It is necessary at this point to also draw attention to methodological changes in the statistical records of international migration to Budapest and Prague. In the case of Budapest, retrospective data are not comparable, because since 1995 they have been processed using other methods. Until 1994, data were obtained from the Register 
of the Ministry of Interior as of 31 December 1996; the figures from 1995 were obtained from the Registry Office for Migration and Nationalities as of 1 January 2000. Since that date, the processing of data of the Registry Office related to the registration of aliens has changed (Gödri et al. 2014). For this reason, international migration to Budapest is evaluated only since 2001. International migration to Prague is available throughout the entire period of investigation, but it should be borne in mind that since 2001 the number of migrants has included foreigners granted asylum and staying longer than 90 days in one calendar year. Since 2004, European Union citizens with long-term or temporary residence in Czechia have also been counted. Finally, Bratislava, has categorized data for external and internal migration since 1992.

\section{Historical background}

The city and its population is a very dynamic concept. In its current structure, it still reflects long-term social development. Therefore, before the change of age structure of the population is analysed, it is necessary to identify the initial position of the capital cities in question. Their status after World War II indicates some similarities and differences for further development. The direct consequences of war can be considered as significantly uneven. Warsaw was most directly affected by the fighting, with up to $85 \%$ of the city centre completely destroyed. Other cities recorded significantly smaller and more uniform damage. However, the functional position of the capitals changed. Budapest and Warsaw continued in their function, although on much smaller administrative areas. Prague regained Slovakia under its administration in addition to Czechia (until 1993). On the other hand, however, after its incorporation into the Eastern bloc it lost its function as a liberal and democratic link between Western and Eastern Europe; this role was taken over by Vienna. Bratislava was an entirely different case, as until then it had the limited function of an administrative centre.
The new social situation in this area also brought convergent trends. All of the cities gained new populations due to the post-war movements. On the other hand, during the period of socialism the cities lost administrative control over their territory. The new socialist regime was characterized by central planning, i.e., control from above. Although at this time, there were planned migration flows from the countryside to the cities, primarily in medium-sized cities with mining or engineering activity, and where the majority of investment was directed. Subsequently, in 1957, Khrushchev introduced a new political ideology which was progressively discussed by all V4 countries. This policy led to the mass construction of pre-fabricated apartment buildings in the affected towns, which culminated in the 1970s and significantly rejuvenated their age structure. In Bratislava, Prague and Warsaw construction was almost entirely limited to cooperative and rental apartments. In Budapest, the situation was more liberal, and to a lesser extent private construction also took place. Yet in all the towns, construction was severely limited and constrained (including the lack of support for transport and service infrastructure) and the capital cities grew more slowly than other cities in the V4 countries (Mykhnenko \& Turok 2007).

\section{The transformation of the population age structures in the capitals of the Visegrad group countries}

The majority of the European population (71\%) lives in cities (Gerőházi et al. 2011). The urban population in terms of demo(geo)graphical research is the first representative and carrier of change in the landscape (Bleha et al.) that brings the economic and social transformation of society, including radical manifestations of the second demographic transition.

However, post-socialist cities such as the capital cities of the Visegrad Group (V4) countries are specific to the European space. Because of this, they are part of the Euro- 
pean 'shrinking urban areas'. These cities suffer from population loss (in most cases between $1-4 \%$ ). Within the EU, there are few places with appreciable increases in population. The changes in demographic behaviour in this area took place in a relatively short time and their internal mechanism differed significantly. The changes were heavily influenced by the transformation of social and political conditions that brought economic and social problems. They were also reflected in changes in family behaviour (Káčerová \& Ondačková 2015).

A hexagonal diagram provides a comprehensive look at the transformation of the age structure of the V4 capitals (Fig. 1) and captures their radical changes. The first period of change between 1980 and 1985 ranks all cities among young populations - rejuvenating bottom-up and also top-down. Growth in the proportion of children, however, is differentiated. The strongest growth occurred in the population of Warsaw, while the lowest was recorded in Budapest. The level of representation of children in 1985 was highest in Bratislava, where the child population still accounted for a quarter of the total population. Prague followed with one fifth of the population represented by children. In Budapest and Warsaw, the proportion of children in the population was less than $20 \%$. In the case of the Warsaw, it is necessary to emphasize the faster aging process of the Polish capital as well as the country itself. The top-down aging process from 1980 to 1985 did not occur because the proportion of those aged 65 and over declined. It was due to the lower number of births in WWI entering this age group. Although in this period we can see the beginnings of the second demographic transition in Central Europe, it is not yet reflected in the age structure of the major cities.

In subsequent periods (1985-1990 and 1990-1995-2000) both, bottom-up and top-

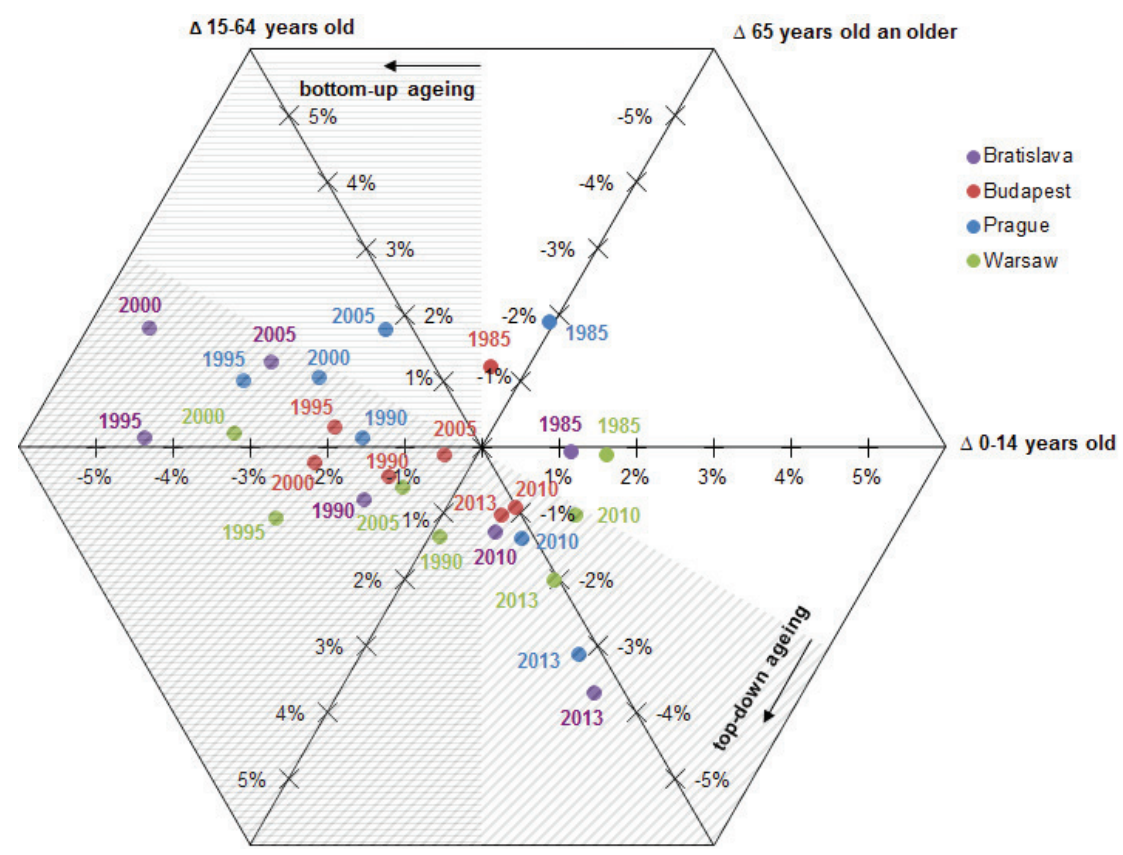

Figure 1. Hexagonal chart of population age structure in the Visegrad Group capitals between 1980 and 2013

Source: own calculation based on CZSO (2015), GUS (2004-2014), KSH (2003-2014, 2015), SOSR (1992-1997, 2015). 
down aging processes are reflected in all V4 capital cities. Their intensity or speed is variable and differs from the position of the parent country capitals in the level of population aging. In the second half of the 1990s, the aging process from the bottom was manifested most notably in the Slovak capital. The proportion of children in the population of Bratislava declined by more than four percentage points due to the significant postponement of motherhood and parenting. A decline was also recorded in the populations of Prague and Warsaw. The aging from the bottom in Budapest was not so radical because at the start of the reporting period it was much older.

Development tendencies toward aging from the bottom between 1995 and 2013 were disturbed between 2005 and 2010 and continued in this trajectory until 2013 when the V4 capital cities recorded a fertility recovery (recuperation), which had an impact on the growth of the proportion of children.

The top-down aging process between 1995 and 2013 took place in all of the investigated cities, but in different ways. The growing share of the old population was less pronounced in Prague and Budapest. By contrast, in much younger Bratislava and Warsaw there was substantial growth in the proportion of seniors.

A distinctive feature in the hexagonal diagram is the growth of the productive age group (with the exception of the first period in Warsaw and Bratislava). This situation was not affected by migration losses. In fact, the growing share of the productive population only affected two major population cohorts from the 1950s and 1970s. A decline in the proportion of 15 to 64 year olds in the populations of the capital cities was registered between 2005, 2010 and 2013. It is the result

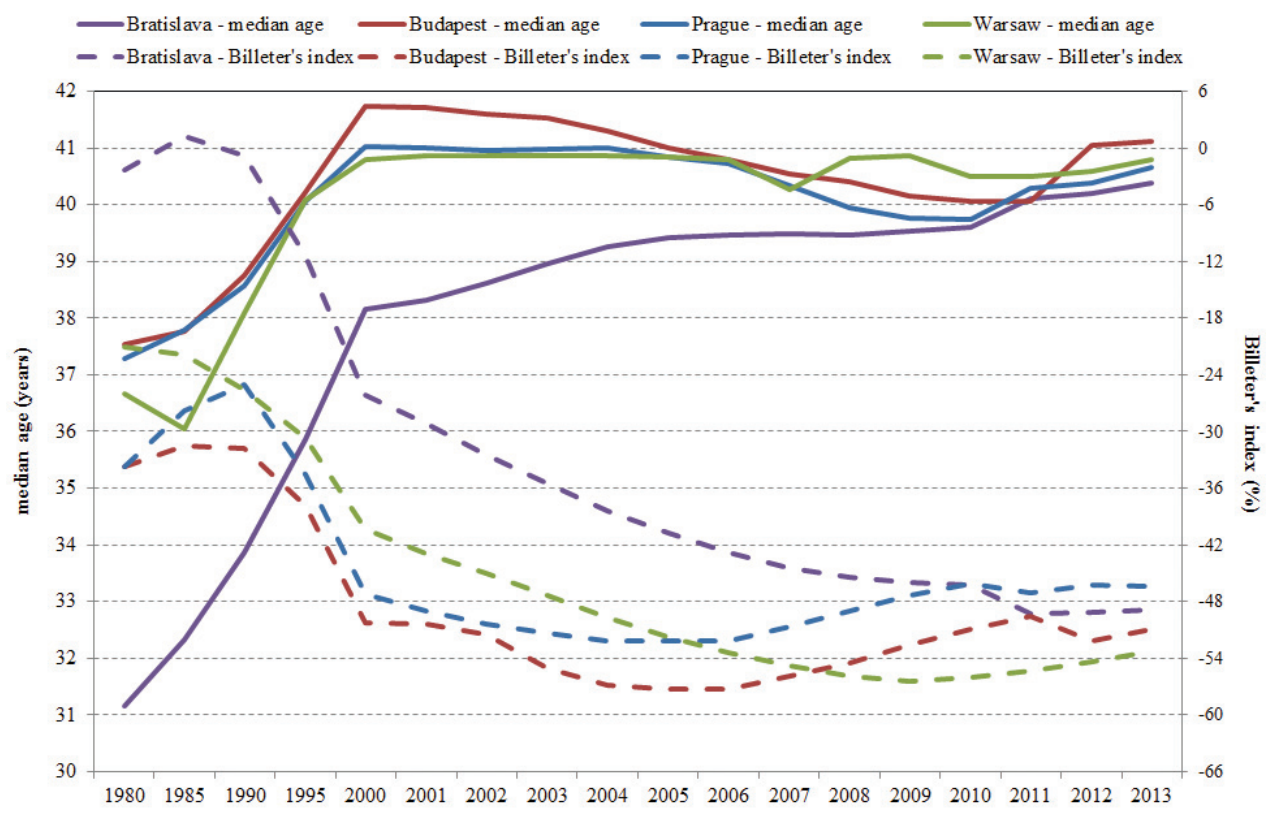

Figure 2. Median age and Billeter's index in the Visegrad Group capitals between 1980 and 2013

Source: own calculation based on CZSO (2015), GUS (2004-2014), KSH (2003-2014, 2015), SOSR (1992-1997, 2015).

Notes: Billeter's index $=$ Population 0-14 - Population 50+/Population 15- 49 * 100 
of their structural character, as those born after World War II leave this age group.

An important predictive value is the median age which divides the population into two equally large parts. The curves confirm previous trends (Fig. 2). The median age in Bratislava was only 31 in 1980, while in the three other capitals it was approximately 6-7 years older. Bratislava had a younger age structure as a result of mass pre-fab construction in the Petržalka district, where 48,755 residents, mostly young families, found housing up to 1980 . In 1991, this district had a population of 128,251 , which accounted for a third of the population of the Slovak capital.

The variance of the median age of the Visegrad Group (V4) capitals decreased to 0.74 years by 2013. In terms of median age, Bratislava has the most progressive age structure. At the same time, it has the fastest aging process. Over the course of 33 years, it has aged nine years, while other cities have increased by an average median age of three to four years. A similar difference in the level of population aging can be seen in the development of the Billeter's index. Its curve indicates a fundamental difference between Bratislava and the other three major cities. The Slovak capital remained in positive figures until the mid-80s. The three other major cities have similar levels of population aging, with a predominance of post-reproduction population segments over pre-reproduction ones already in 1980.

\section{Population dynamics}

The cause of the changes of the age structure is revealed by the evolution of the main demographic processes. The general difference in the dynamics of the population can be identified in a Webb graph (Fig. 3). In 1990, Bratislava, Prague and Warsaw showed total population growth. The decisive factor in the crude rate of total increase in the populations of Prague and Warsaw was again the crude rate of migration, which compensated for the natural population decrease. In the case of Bratislava, both elements of the overall gain were positive. In the initial year of monitoring, Budapest was the only city with a total population decline, and it maintained this status up to 2000.

A common feature of all Visegrad Group (V4) capital cities from 1995 to 2005 was the natural population decline, which was a consequence of the spread of a new model of family and reproductive behaviour. This period has in fact contributed to the aging of age structures in the V4 capitals. While in later years Bratislava and Prague were to see a positive natural increase, Budapest remained in the negative territory. The development in the crude rate of natural increase in Warsaw is fluctuating; on the other hand, migration population growth is clearly indicated throughout the entire investigated period. Likewise, there is migration growth in Bratislava, with the exception of the year 2000, and Prague, with the exception of the years 2000 and 2013.

The tendencies of population dynamics in the capital cities sketched out above suggest variance for the changes in its age structure. The causes of differential development of age structures, especially the intensity of the process of population aging, can be identified in an analysis of individual demographic processes.

\section{Transformation of fertility and family behaviour}

The period from 1990 to 1995 was accompanied by a larger rate of natural population decrease, and in the case of Bratislava, a transformation from natural increase to decrease. When looking at Figure 3 , it is clear that the dominant cause of this change was the sharp fall in the crude birth rate, not only in Bratislava, but in all four capitals. This process was most significant in the case of Bratislava, whose birth rate fell from $12.22 \%$ o in 1990 to $7.53 \%$ in 1996 ; to some extent this was related to the termination of intended fertility in Petržalka, the aforementioned largest and newest residential complex of the capi- 


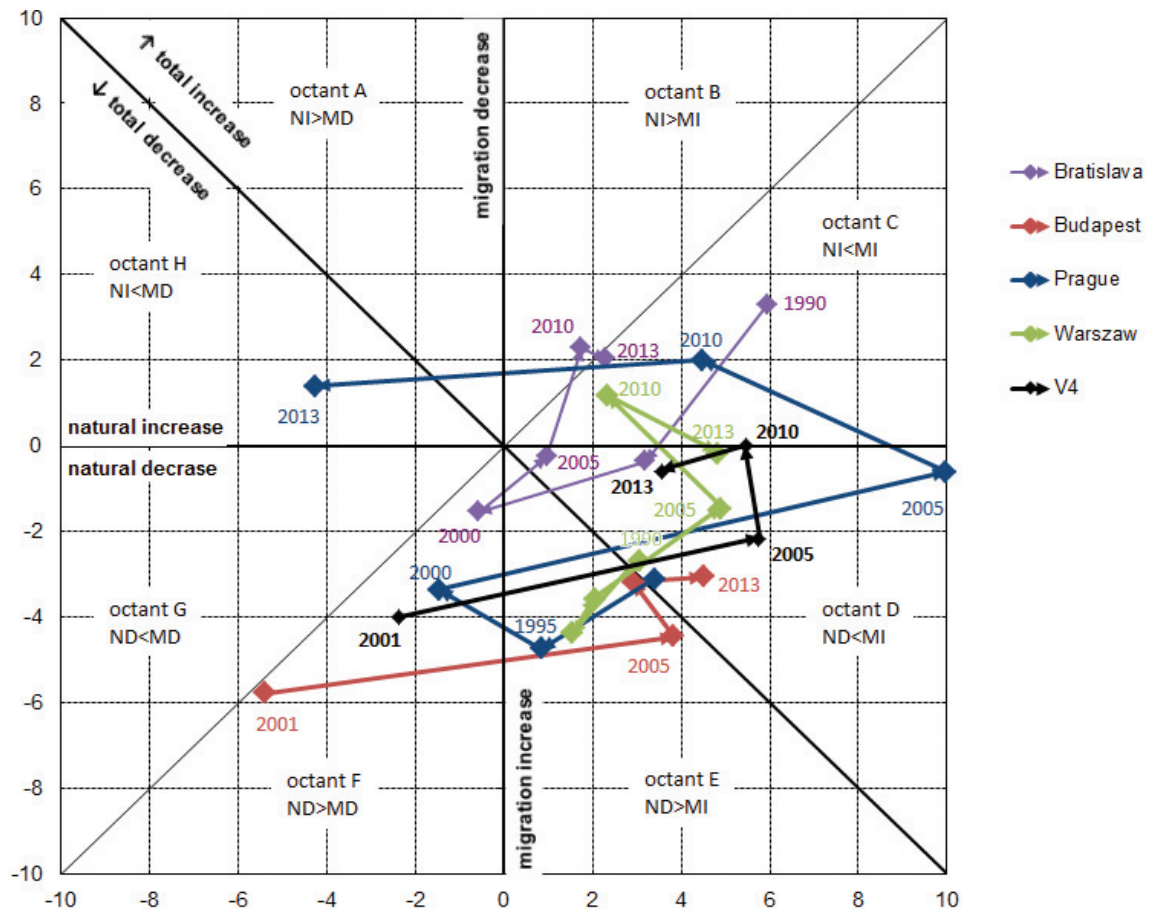

Explanation: NI - natural increase, ND natural decrease, MI - migration increase, MD migration decrease

Figure 3. Webb diagram of population in the Visegrad Group Capitals between 1990 and 2013

Source: own calculation based on CZSO (1991-2014), GUS (2007, 2004-2014), KSH (2005, 2015), SOSR (1992-1997, 1993-2014).

tal. Thus, the originally young age structure of Bratislava quickly approached the age structures of the other cities. The proportion of children in Bratislava declined in the 1990s by 10 percentage points.

The decline in the birth rate of the populations of the V4 capital cities was influenced by several factors. The determining factor in the development of these countries was the change in political regime, which came about as a result of the introduction of democracy. The temporary 'freeze' in the birth rate, as well as in marriages and divorces, is often seen as a rational response to the new institutional and economic environment after the fall of the Iron Curtain at the end of 1989. A new currency, new laws, massive economic restructuring, high unemployment, but also new opportunities were introduced almost overnight (Conrad et al. 1996). The urban population reacted to this transition with an immediate change in reproductive behaviour.

In the capital cities, regime change led to a significant change in the sectoral structure of the economy. While the socialist model emphasized industrial production, the new capitalist system quickly reshaped the cities in its image, with an emphasis on the tertiary sector. This resulted, on the one hand, in the rapid growth of unemployment, and on the other, significant interest among the young population in undergraduate studies focused on the new requirements of the labour market. Therefore, due to economic problems (a decline in real wages), older couples stopped having children. The younger generation, meanwhile, postponed starting 
a family until a later age, after finishing their studies and securing separate housing. At the same time, after years of massive socialist construction, the housing and real estate market was taken over by private investors. Construction was insufficient, leading to disproportionately high prices of apartments that were unattainable for the young population without long-term mortgages.

Besides the obvious economic changes, the fall of the Iron Curtain brought about new ideologies connected with the second demographic transition - a collection of changes in the behaviour of the population. Among its most striking features are individualism, personal freedom and growth in the use of contraceptives. These manifestations are a reflection of demographic behaviour, especially in terms of the increased average age of marriage and first birth, and the related decline in marriage and marital fertility. In the family, we identify behavioural transformation from families to singles, cohabitation and single-parent families.

The development of the crude birth rate (Fig. 4) stagnated at 6-8\% until the late 1990s. It is surprising that the lowest rate remained in Warsaw up to 2000. Again, we note a certain divergence of this process in comparison with the evaluation of each country as a whole. In comparison with other European cities, Warsaw is characterized by a high number of marriages, fewer divorces and a high degree of religiosity (in 2011 up to $86 \%$ of the population of Mazovia Province, including the capital, Warsaw, reported church membership). Thus, although the principles of the second demographic transition apply in Warsaw, as a conservative metropolis, to a limited extent, its birth rate is among the lowest. The reason for this can be found in the (missing) population policy, to which the inhabitants were accustomed during the socialist era. Political attention to transforming the country was focused on economic reforms and solving problems in the social sphere after 1989 (poverty linked to unemployment). Family policy was seen as an infringement of personal freedoms of the popula- tion, and appeared obsolete. Macura (2000) states that one of the main reasons behind the decline in the birth rate in Poland was the reduction in state aid in 1990, which made raising children less attractive. As a result, in the early 21 st century Warsaw became the oldest capital of the V4 countries in terms of aging from the bottom.

The period of 2000 to 2005 was again characterized by convergent trends. In all of the investigated populations there was a renewed birth rate. These mainly consist of birth postponement leading to the so-called process of 'recuperation'. This was evidenced by the increasing specific fertility rate by age.

The last seven-year period of 2005 to 2013 brought certain specifics in terms of the crude birth rate. Bratislava, Prague and Warsaw saw continuous growth in the birth rate up to 2010-2011, with Bratislava again displaying its former dominance. However, the value of the number of births in Bratislava in 2011 can be considered methodologically overvalued, caused by aligning data (population decline) after the census. Conversely, Budapest, which originally showed a lower drop in the birth rate, recorded a lower rate of recovery and an earlier stagnation of fertility rates (affected by the economic crisis of 2008). In recent years, however, a stagnation or even slight decline can again be identified in all V4 capital cities, and the proportion of children ages 0-14 was likewise stagnant between $12-14 \%$ in 2000-2013.

\section{Catching up with the trends of mortality in Western Europe}

Mortality rates in Eastern and Central Europe have been and are significantly higher compared with the mortality rates in Western Europe. In the mid-1960s, all of the countries of Europe transitioned from the second phase (the period of retreat of the pandemic) to the third stage of the epidemiological transition. This third phase, i.e., a period of degenerative stress and human conditioned diseases, can be divided into two separate sub-phases. 


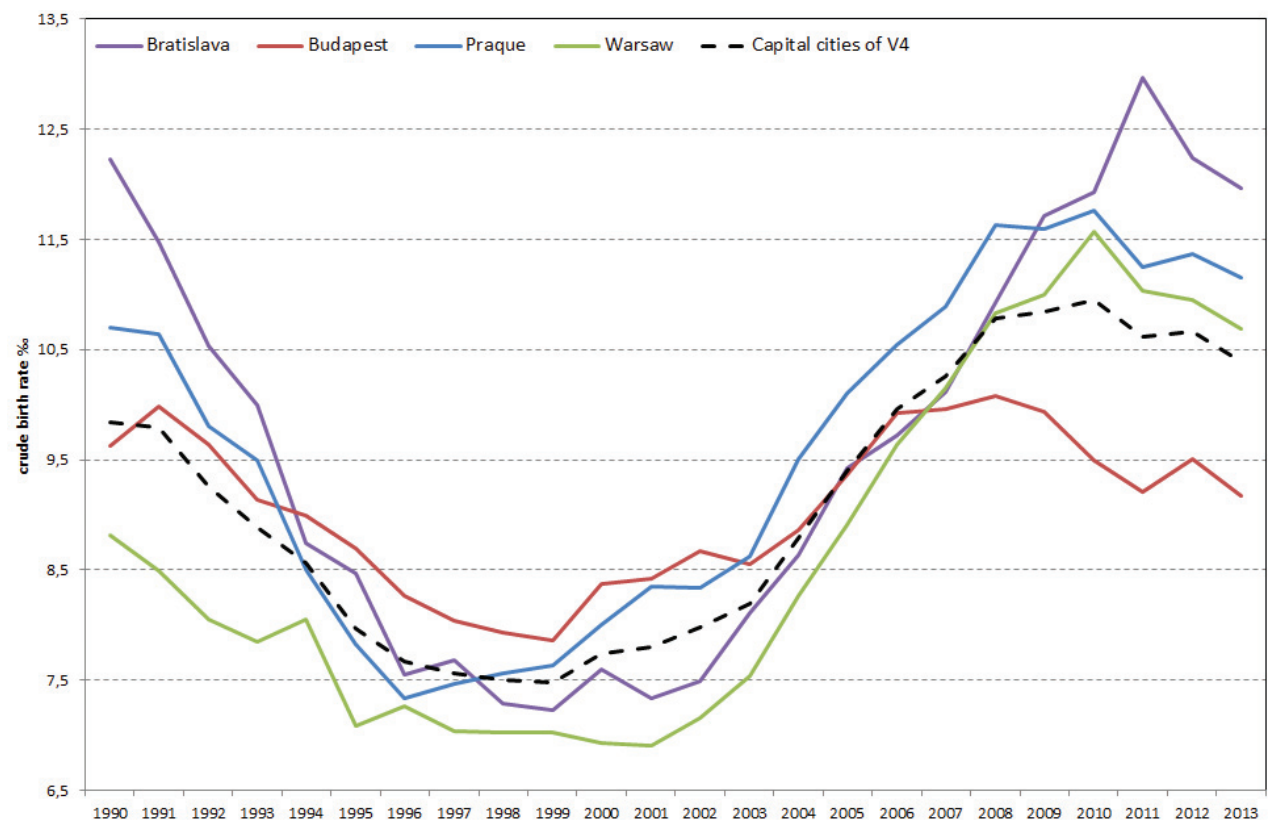

Figure 4. Crude birth rate in the Visegrad Group Capitals between 1990 and 2013

Source: own calculation based on CZSO (1991-2014), GUS (2007, 2004-2014), KSH (2005, 2015), SOSR (1992-1997, 1993-2014).

The fundamental difference between them is that in the first sub-phase, disease prevention and stopping or slowing their progress is minimal, while in the other sub-phase, a substantial part of degenerative diseases can be prevented, especially those linked with aging, because they can be postponed or their progress can be slowed (Józan 2008). The transition from first to second sub-phase was interrupted in Central and Eastern Europe by forced incorporation into the Soviet bloc. This fact also directly affected the different structure of mortality by cause of death (Meslé \& Valin 2002; Langhamrová 2010). Above all, the percentage of deaths due to diseases of the circulatory system in the affected populations is above average in comparison to Western European countries, where it is relatively equal to cancer as a cause of death. These tendencies can be observed in the V4 capitals. Compared to the general population of the countries, however, cities have some specifics: high population density, higher ethnic, cultural and religious diversity, and provision of services for the population such as health care, education and social services, which are usually quite accessible (Vlahov et al. 2007). Thanks to these improvements, mortality in urban centres is more favourable.

While infant and child mortality in the investigated cities is near the biological limits, the changes affecting mortality rates in the current phase of population development exclusively affect adult mortality or mortality of the elderly population. Thus they shape the intensity of the aging process from the centre or above the age pyramid. The beginning of the reporting period was accompanied by stagnation, in the case of Poland and Hungary capitals by the growth of the crude death rate also, culminating in 1991 and 1995 respectively (Fig. 5). To specify the causes of the different mortality development is an extremely challenging task (see text below) It could be explained by the political changes that occurred after the fall of communism, which 
led to inequalities associated with a healthy lifestyle, such as alcohol consumption or differences in the efficiency of or access to health care (Marmot et al. 2012). In general it can be said, that the impact on health and mortality was caused by various socioeconomic factors (unemployment, education, social deprivation). The Borrell study (2014) demonstrated the significant effect of these factors among men in all European cities. The authors argue that the socioeconomic inequalities in mortality were more pronounced for men than women, and relative inequalities were greater in Eastern and Northern European cities, and lower in some Western (men) and Southern (women) European cities. However, in Prague and Bratislava the impact of the factor of education did not prove to be significant, while in Budapest the male unemployment and the women's deprivation significantly increased the risk of death.

After overcoming the problems associated with the post-transformation phase, the crude mortality rate in the V4 capitals (excluding Bratislava) was characterized by a downward trend and mutual convergence of their values to $10-11 \%$ o (Fig. 5). Progress occurred in particular in the treatment of diseases of the circulatory system, as well as mortality due to external causes. The improvements were enabled by the emergence of a healthier diet, new medicines, as well as the exchange of experience in the medical field with the countries of Western Europe. In terms of age, there was a breakthrough in mortality in the 30-70 age group. After years of deterioration in mortality rates in the adult population, it is the productive age group that contributes most to rising life expectancy.

A large variation in the range of crude death rates in 1990 indicated certain national specificities of mortality rates. Budapest had the highest crude mortality rate, an average of 2 points in comparison with the total population of the V4 capitals. This was partially the result of the 'overage' Budapest

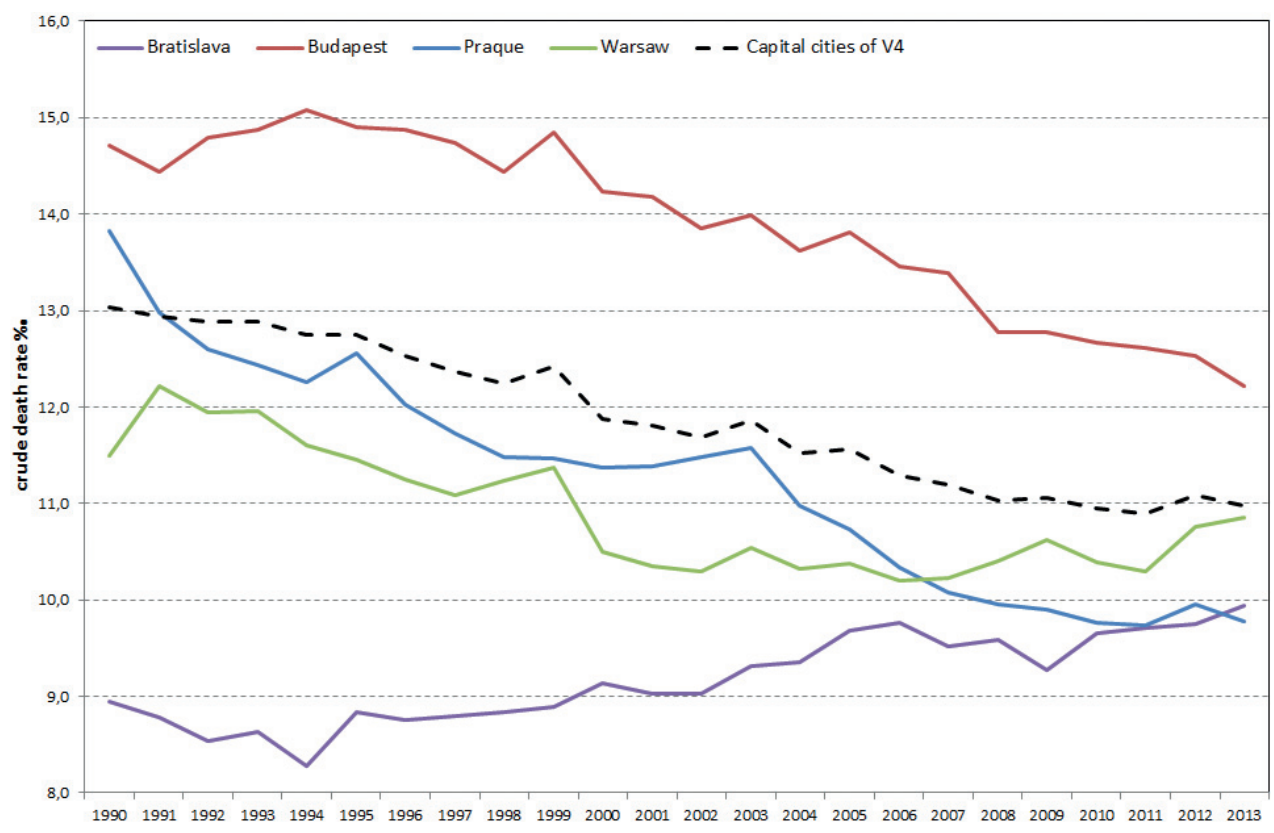

Figure 5. Crude death rate in the Visegrad Group Capitals between 1990 and 2013

Source: own calculation based on CZSO (1991-2014), GUS (2007, 2004-2014), KSH $(2005,2015)$, SOSR (1992-1997, 1993-2014). 
population on one hand and the general lag in the overall development of the mortality rate of the Hungarian population on the other. Hungary, after all, had to make up for the significant decline from the previous period, when the average life expectancy of men dropped from 67.5 in 1966 to 64.7 in 1993 (Káčerová \& Ondačková 2015). The less favourable situation of Budapest mortality rates compared with other major cities was caused mainly by the poor lifestyle of the population. Excessive consumption of alcohol (Baracs pálinka - fruit brandy) and cigarettes, as well as unhealthy eating habits (with excessive amounts of salt and fat) significantly contributed to an increase in deaths from digestive problems (particularly cirrhosis of the liver), cancer of the respiratory system and cardiovascular diseases, as well as deaths from external causes. According to estimates, cigarettes in the past led to $19-21 \%$ of all deaths and alcohol 11-13\% (Józan 2008). The situation was unfavourable, especially among low-educated population, such as unskilled and semi-skilled workers and farm labourers, but it was partly eased by Gorbachev's antialcohol campaign in 1985, which Hungary joined. According to Andorka et al. (1999), Hungary was also characterized during this period by a lack of public health infrastructure. This created room for the later decline in deaths from infectious diseases during the next reporting period. The decline in the crude mortality rate in Budapest was most pronounced in comparison with other V4 capital cities, at almost 2.5 per thousand. It was the result of the decline from the high values. Yet even today, Budapest has the highest crude death rate and, therefore, lags behind the other V4 capitals cities in life expectancy at birth by 2-3 years.

The curves in the crude death rates of the populations of Prague and Warsaw follow the same trend and oscillate at approximately the same values (+/- 1 point per mille). The observed development of the mortality rate in Prague has been declining (except in 1995 and in 2003). Among the investigated populations, Czechia has the most favourable mortality rate. The position of Prague suggests that it will be the fastest to catch up with west-European countries in improving mortality rates within the evaluated area of Central and Eastern Europe. Among others, it is the result of more favourable mortality rates of men, with the difference between the life expectancy of the sexes at 5.0 years, while in the remaining capital cities it is from 5.9 to 6.8 years.

Significant progress was seen in the population of Warsaw, mainly due to improvements in mortality in the group of cancer, circulatory and digestive diseases. As the decline in mortality occurred mainly among women in the age group over 55 years, further assumptions for population aging in the Polish capital were formed.

Bratislava had the most progressive age structure in the initial year of monitoring and also the lowest crude death rates. Due to its intensive process of ageing, the growth of its crude death rate is an expected phenomenon. Furthermore, in comparison with other V4 capitals, the treatment of cardiovascular disease is less successful (Jurkovičová 2005: 17). What also becomes problematic is mortality from cancer in those aged 60 years and over, which slows the growth of the oldest age categories. And so, while the other three capital cities recorded an 18-19\% proportion of seniors in the population, Bratislava only recorded $15 \%$.

\section{Suburbanization and the growth of foreign migration}

The population size of major cities is also affected by migration increase or decrease. Its influence on the age structure itself can be identified only in migration increase by age. Such data are not available. Therefore, the following facts represent only the potential impact on the age structure of the evaluated urban populations.

The development of international migration was observed for each unique population. After all, only two pairs of places based 
on their similarity can be created. The first pair consists of Bratislava and Warsaw, which have a low intensity of international migration gains (Fig. 6). The international migration does not significantly influence the age structure of the V4-capitals. From the perspective of migratory movements, the countries of Central and Eastern Europe can generally be considered transit countries (Gödri et al. 2014).

On the contrary, Budapest and Prague recorded a higher rate of migration gains, which especially in the case of Prague can be considered influential and important. It is necessary to emphasize that the rate of migration to the Czech capital is affected by methodological changes in migration statistics (see part Methodology). Prague has grown mainly due to the migration of foreigners who were granted residence. The crude rate of net migration amounted to $21 \%$ in the period of economic growth between 2007 and 2009. After this period it was followed by a significant drop in the migration balance, which was also due to the negative impact of the economic crisis on the number of job vacancies. In this case, the impact on the age structure of Prague is clear, since the increasing number of immigrants was the result of the concentration of job opportunities. The aforementioned facts cause slow population growth mainly in the productive age (CZSO 2008).

Foreign migration to Budapest is similarly subjected to a change in the recording of migration statistics. The positive foreign migration growth of the Hungarian capital was conditional upon Hungary's accession to the EU. By 2005, the number of registered immigrants exceeded 25,000 (Gödri et al. 2014). On average, $44 \%$ of those who settled in Budapest between 1990 and 2010 did so because it offered job opportunities (Gödri 2012). Another important factor in this regard was its proximity to the border, which represents an added value

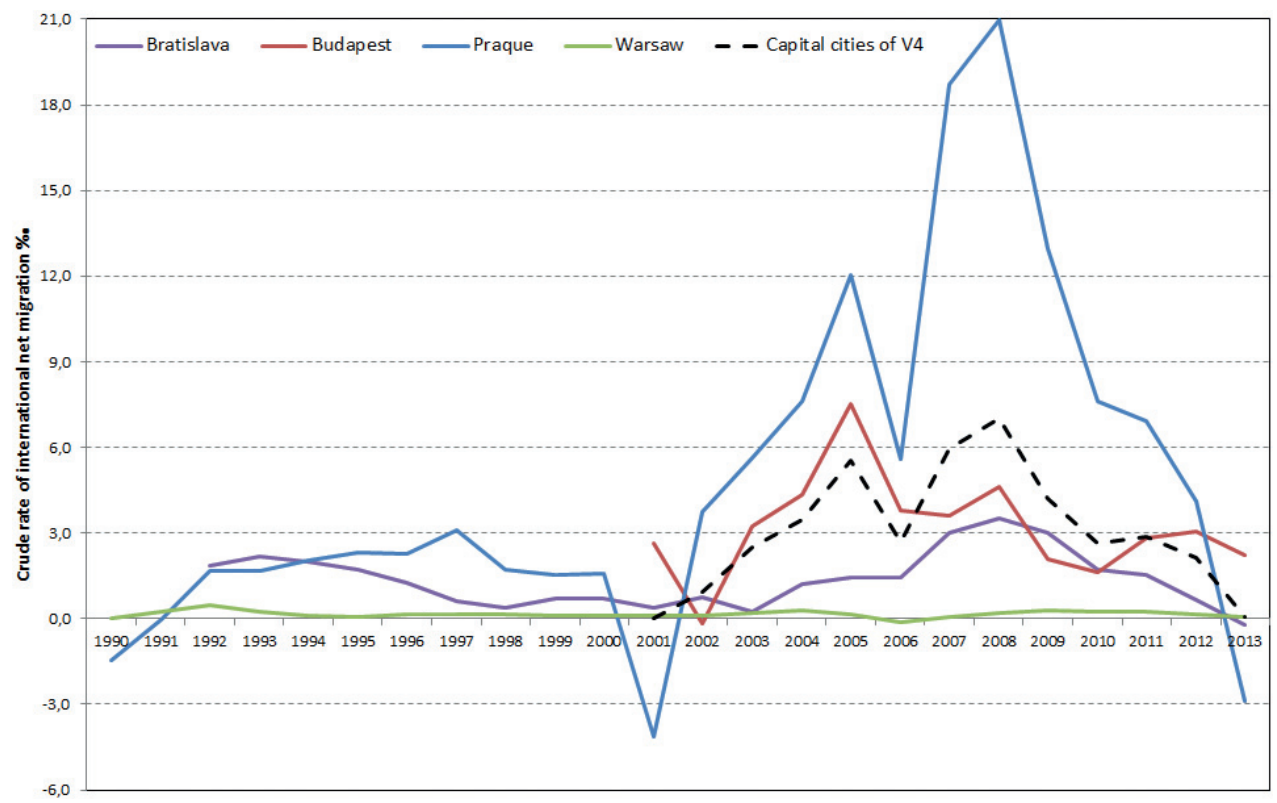

Figure 6. Crude rate of international net migration in the Visegrad Group Capitals between 1990 and 2013

Source: own calculation based on CZSO (1991-2014), GUS (2007, 2004-2014), KSH $(2005,2015)$, SOSR (1992-1997, 1993-2014). 
for many migrants. In 2008, Hungary simplified the legislative conditions for granting long-term residency and asylum, which was also reflected in a slight increase in net migration to Budapest. Characteristic of the growth in net migration was the immigration of ethnic Hungarians from Romania and the former Yugoslavia. The simplified naturalization process introduced in 2010 and coming into force on January 1, 2011 made it possible for people with Hungarian ancestry to gain Hungarian citizenship even without residing in Hungary. This inevitably leads to the growth of the number of new citizens. Citizenship is no longer granted exclusively to immigrants, so the percentage of this group within the foreign population residing in the country has lost its relevance since 2011 (Godri 2012).

Internal migration in relation to large European cities is characterized by a decline since the mid-1990s in migration gain up to higher growth of migration loss. The urban populations of Eastern and Central Europe are no exception. It has to do with the process of suburbanization, which has become a major deconcentrating urbanization trend in this period. In essence, the intra-regional redistribution of the population does not mean just population growth in suburban communities, but involves complex changes in the spatial organization of society and activities in the regions around cities (Šveda 2011; Popjaková \& Blažek 2015). Similarly, the changes concern the cities themselves, leading to the out-migration of the population, therefore the 'loss' of the productive population, etc.

Budapest, Bratislava and Prague were the capital cities of the V4 countries in which migration balance reached the most pronounced decline of values in the mid-1990s (Fig. 7). In the early 1990s, Budapest lost $15 \%$ of its population, while its suburbs grew by $20 \%$ (Soos \& Ignits 2003). The population loss in the Hungarian capital culminated in 2000 when it reached $-10 \%$. At the turn of 2007 and 2008, the population of Budapest began to grow again after almost 20 years of massive decline, with a total loss of nearly 300,000 inhabitants. The deconcentration migration flow of the population is constant. But there is also a counter flow of individuals who returned to the Hungarian capital. They confirm the re-urbanization concentration trends in the case of Budapest. There are a number of reasons for this, but the decisive one is the rising cost of living in urban areas. At the same time, it is also linked to the lack of transport infrastructure that makes commuting time-consuming and inconvenient (Egedy 2011). Since 2009, Budapest has seen a net gain in internal migration. In the last five examined years, these gains are close to the values before 1991 (oscillate around 2\%o).

Bratislava and Prague have similar developments in the crude rate of migration balance of internal migration. The migration losses are generally much lower compared to Budapest. The stimuli for emigration from Prague (as with all large cities) were significantly lower land prices on the outskirts, and the lower cost of living and housing in suburban areas. Housing policy, which aimed at supporting the construction of houses, as well as relatively inexpensive suburban services and a quality natural environment in some areas outside the Czech capital also played a role (Ptáček 1998). In 1994, Prague had a negative migration balance for the first time in its post-war history. This change is related to the turnover in the character of net migration in the districts of Central Bohemia. Among other general factors affecting the suburbanization process of Praque, there were other facts. For example in the Nymburk district, new land made available by the closing of the military complex in Milovice especially played a role (Ouředníček 2007). In the case of the Benešov district, there was the unsettled SS training camp ground at Neveklovsko (Fialová \& Vágner 2005). Unlike Bratislava, Prague steadily lost population due to internal migration. Slight net migration was recorded only in 2002-2003 and 2007. By 2013, the value of migration balance decreased to $-2 \%$.

Bratislava, which lost population to migration since the mid-1990s, was also subject to suburbanization trends. The most intensive 


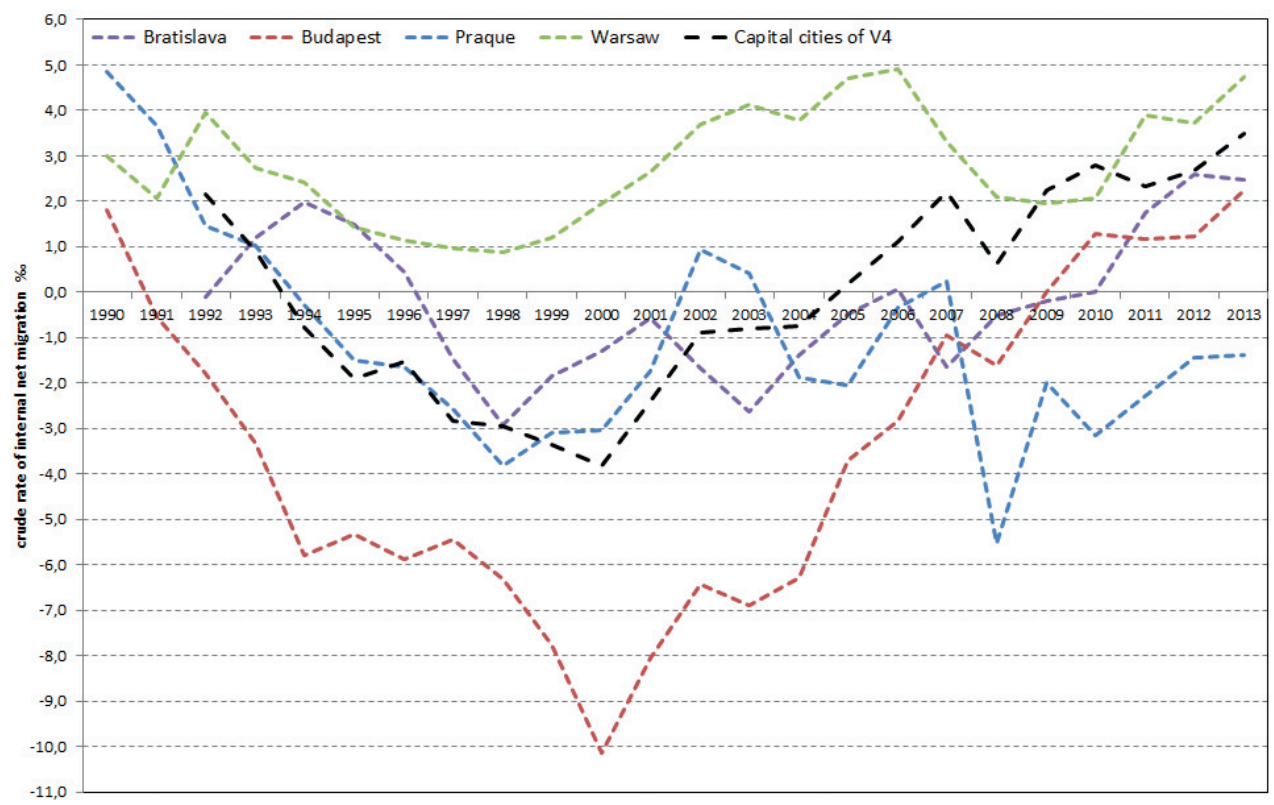

Figure 7. Crude rate of internal net migration in the Visegrad Group Capitals between 1990 and 2013

Source: own calculation based on CZSO (1991-2014), GUS (2007, 2004-2014), KSH $(2005,2015)$, SOSR (1992-1997, 1993-2014).

migration loss was seen in the Slovak capital in the period of 1996-1999, with an average of $1.45 \%$. An important role in the process of migration in Bratislava was played by the demographically youngest district Petržalka, which was built as the largest residential complex in Slovakia in the late 1980s. From 1996-2005, Petržalka migration changed from positive to negative. Petržalka's share in the suburbanization processes increased as the intensity of migration of its population to districts outside the capital rose in Senec, Malacky and Pezinok and elsewhere (Bleha \& Popjaková 2007). Later out-migration from Bratislava became more moderate. From 2005-2009, the losses did not reach more than $-0.5 \%$. The downward trend of migration losses of the capital turned into migration gains in 2010-2013. This stems from the lack of infrastructure in Bratislava's hinterland (similar to the situation in the Hungarian capital).

Warsaw has a very specific position in that the fall in the crude rate of net migration growth occurred mainly in 1995-1999. In that period, however, the value of this indicator did not fall into the negative. Overall, Warsaw had positive migration for the entire period. It has the highest value of net migration (5\%). Deconcentration of the population in Poland accelerated earlier, as was the case in Western countries (Kupiszewski et al. 1998). The main reason was that in Poland during the period of relatively low-level urbanization and with the existing major social disparities between urban and rural areas, the suburbanization process was linked to the transformation of rural areas surrounding large cities into contiguous urban areas (Lisowski 2004).

\section{Conclusion}

The similarity of the development of the age structure of Slovakia and Poland as well as the similarity of Hungary and Czechia demonstrated in the previous analyses of the Visegrad Group countries is not confirmed by the development of age characteristics 
of their capitals. The investigated urban populations of Prague, Bratislava, Budapest and Warsaw have undergone significant changes in the context of their long-term socio-political development. An analogous intensity of the transformation process of aging urban populations was identified in Prague, Warsaw and Budapest. When comparing the age structure of the V4 capital cities, Bratislava is characterized by unique development.

It is possible to identify four phases of transformation of the age structure of the capital cities. The causality of the transformation process of population aging in the V4 capitals in various stages is varied. The first phase is the period of 1980-1985, when we can talk about the fading of the stage in which the population gets younger. In this period in the Central European area we can see signs of the second demographic transition. Its reflection in the age structure of the capital cities had not yet occurred.

In the second 15-year period (1985-2000) there is a fundamental change of age structure, i.e., to a radically aging population. The evaluation of the capital cities is significantly differentiated by the intensity of population aging. Prague and Budapest as the older cities (with earlier onset of the second demographic revolution), demonstrate slower population aging. Conversely, in Warsaw and Bratislava we can see dynamic changes related to the significant decrease in fertility.

A decisive proportion of the aging of the Czech and Polish capitals in this transformation phase was due to improving mortality rates, especially in the areas of cancer and circulatory diseases. The effect of migration on the aging population is particularly evident in Prague and Budapest.

The third period of 2000-2010 in the development of the age structure is the gradual aging in all of the analysed capital cities. This is compounded by the recovery of fertility, the realization of so-called birth postponement. In this period, the rejuvenating effect of migration on the age of the population can be seen. In the case of the Czech capital, it is partially due to the influence of high international migration gains (up to $21 \%$ ). Other capital cities, on the contrary, benefited from gains from internal migration.

The fourth and last period (2010-2013) is characterized by age stagnation, whereas the decisive factor for this condition is a stable level of fertility.

\section{Acknowledgements}

The publication has been financially supported by The Research and Development Assistance Agency of the Slovak Republic No. APVV-15-0184 Intergenerational social networks in an aging city - continuity and innovation and by the Grant Agency of the University of South Bohemia in České Budějovice No. 160/2016/S Key competencies in the context of the inter-linkages of science subjects.

Editors' note:

Unless otherwise stated, the sources of tables and figures are the authors', on the basis of their own research. 


\section{References}

Andorka R., Kolosi T., ROSE R., VUKOVICH G. (eds.), 1999. A society transformed: Hungary in time-space perspective. Budapest: Central European University Press.

Arltová M., Langhamrová J., 2010. Migration and ageing of the population of the Czech Republic and the EU countries. Prague Economic Papers, vol. 19, no. 1, pp. 54-73.

BıČík I., AnděL J., HavlíčEK T., 2010. Makroregiony světa: regionální geografie pro gymnázia. Praha: Nakladatelství České geografické společnosti.

BiJak J., Kupiszewska D., Kupiszewski M., SaczUk K., Kicinger A., 2007. Population and labour force projections for 27 European countries, 2002-052: Impact of international migration on population ageing. European Journal of Population/Revue Européenne de Démographie, vol. 23, no. 1, pp. 1-31.

BleHA B., ŠPROCHA, B., VAŇo, B., n.d. Štúdia demografického potenciálu hlavného mesta Slovenskej republiky Bratislavy do roku 2050. http:// www.bratislava.sk/assets/File.ashx? id_org$=700000 \& i d$ dokumenty $=11054133$ [6 January 2018].

Bleha B., Popjaková D., 2007. Migrácia ako dôležitý determinant budúceho vývoja na lokálnej úrovni - príklad Petržalky. Geografický časopis, vol. 59, no. 3, pp. 265-291.

Borrell C., Marí-Dellolmo M., Palència L., Gotsens M., Burström B.O., Domínguez-Berjón F., Rodríguez-Sanz M., Dzúrová D., Gandarillas A., Hoffmann R., Kovacs K., Marinacci C., Martikainen P., Pikhart H., Corman D., Rosicova K., Saez M., Santana P., Tarkiainen L., Puigrinós R., Morrison J., Pasarín M.I., Díez È., 2014. Socioeconomic inequalities in mortality in 16 European cities. Scandinavian Journal of Public Health, vol. 42, no. 3, pp. 245-254.

BUCHER S., 2012. Aspects of the phenomenon of demographic population aging in Czechia and Slovakia: Time and regional dimensions. Human Geographers - Journal of Studies and Research in Human Geography, vol. 6, no. 1, pp. 33-25.

BUCHER S., 2014. Selected indicators of population ageing in new member states of the European Union. Middle-East Journal of Scientific Research, vol. 22, no. 4, pp. 545-552.
Conrad C., Lechner M., Werner W., 1996. East German fertility after unification: Crisis or adaptation?. Population and Development Review, vol. 22, no. 2, pp. 331-358.

CZSO, 1991-2014. Pohyb obyvatelstva v České republice 1990-2004. Demografická ročenka České republiky 2005-2013, https://www.czso. cz/[12 November 2016].

CZSO, 2015. Age distribution of Prague's population. 31st December, in 1961-2013, territorial breakdown of the given year, https://www.czso. cz/[12 November 2016]

DE BliJ H.J., Muller P.O., 1988. Geography: Regions and concepts. New York: John Wiley.

DIVINSKÝ B., 2001. Postavenie Bratislavy v Stredoeurópskom metropolitnom systéme z populačného hladiska. Geografický časopis, vol. 53, no. 2, pp. 171-190.

DŁugosz Z., 2007. Present state and the perspectives of the ageing of European population. Bulletin of Geography. Socio-economic Series, vol. 8, pp. 17-28.

Egedy T., Kovács Z., 2011. Budapest as a destination of migration: The view of transnational creative workers. Hungarian Geographical Bulletin, vol. 60, no. 2, pp. 161-188.

ENYEDI G., 2009. Welcoming address at the International Conference on 'Challenges of Ageing in Villages and Cities: The Central European Experience!. http://www.human.geo.u-szeged.hu/files/c/Aging/Fejezetek_web_01.pdf [20 March 2016].

Fialová L., VÁGner J., 2005. Druhé bydlení v periférnich oblastech [in:] M. Novotná (ed.), Problémy periférních oblastí, Praha: Univerzita Karlova v Praze, pp. 74-80, http://www.periphery. cz/download/nectiny.pdf [22 January 2011].

Geröházi É., Hegedüs J., Szemző H., Tosics I., 2011. The impact of European demographic trends on regional and urban development. Synthesis Report (Hungarian Presidency of the Council of the European Union), Budapest: Metropolitan Research Institute.

GÖDRI I., 2012. International migration [in:] P. Öri, Z. Spéder (eds.), Demographic portrait of Hungary: 2012: Report on the conditions of the Hungarian Population, Budapest: Demographic Research Institute, HCSO, pp. 135-152. 
Gödri I., Soltész B., Bodacz-Nagy B., 2014. Immigration or emigration country? Migration trends and their socio-economic background in Hungary: A longer-term historical perspective. Working Papers on Population, Family and Welfare, vol. 19, Budapest: Hungarian Demographic Research Institute.

GÓRCZYŃSKA M., 2014. Unique or universal? Mechanisms and processes of social change in post-socialist Warsaw. Hungarian Geographical Bulletin, vol. 63, no. 3, pp. 255-270.

GUS, 2005-2014. Statistical Yearbook of Warsaw 2004-2013. http://stat.gov.pl/en/ [15 November 2016].

GUS, 2007. Ludność Łodzi i innych wielkich miast w Polsce w latach 1984-2006, http://stat.gov. $\mathrm{pl} / \mathrm{en} /[15$ November 2016].

JózAN P., 2008. Main features of epidemiological development in Hungary after the Second World War. Hungarian Statistical Review, Special Number 12, pp. 139-154.

JuRKOVIČOVÁ J., 2005. Vieme zdravo žit?: Zdravotný stav slovenskej populácie 1999 - 2004 a prevencia kardiovaskulárnych a civilizačných ochorení. Bratislava: Lekárska fakulta Univerzity Komenského.

KáČerová M., OndaČKová J., 2015. The process of population ageing in countries of the Visegrad Group (V4). Erdkunde, vol. 69, no. 1, pp. 49-68.

Kovács Z., 2005. Population and housing dynamics in Budapest metropolitan region after 1990 (draft paper). https://borg.hi.is/enhr2005iceland/ppr/Kovacs.pdf [3 January 2018].

KrejČ́ T., Martinát S., Klusáček P., 2011. Spatial differentiation of selected processes connected to the second demographic transition in postsocialist cities (the examples of Brno and Ostrava, Czech Republic). Moravian Geographical Reports, vol. 19, no. 2, pp. 39-50.

KSH, 2003-2014. Budapesti Statisztikai Tájékoztató 2002-2013 - Budapest Statistical Information 2002-2013. https://www.ksh.hu/ [13 November 2016].

KSH, 2005. Demographic trends in East-central capitals. https://www.ksh.hu/ [13 November 2016].

KSH, 2015. Internal migration (from 1990), Vital events (from 2001), Population by age group and sex. https://www.ksh.hu/ [14 November 2016].
Kupiszewski M., Durham H., Rees P., 1998. Internal migration and urban change in Poland. European Journal of Population, vol. 14, no. 3, pp. 265-290.

KUREK S., 2008. Spatial disparities in the changes in the population age structure of Poland in the context of the second demographic transition. Zeitschrift für Bevölkerungswissenschaft, vol. 33, no. 3-4, pp. 271-292.

LANGHAMrová J., 2010. Střední délka života $\checkmark$ České republice a $v$ zemích EU: Life expectancy in the Czech Republic and EU countries. Reprodukce lidského kapitálu 2010. Praha: VŠE, http://kdem.vse.cz/resources/relik10/PDFstudenti/Langhamrova.pdf [5 May 2016].

LIsowski A., 2004. Zmiany warunków życia waglomeracji warszawskiejw latach 1995-2000 [in:] I. Jażdżewska (ed.), Zróżnicowanie warunków życia ludności w mieście. XVII Konwersatorium Wiedzy o Mieście. Łódź: Wydawnictwo Uniwersytetu Łódźkiego, pp. 67-76.

Macura M., 2000. Fertility decline in the transition economies, 1989-1998: Economic and social factors revisited. Economic Survey of Europe, no. 1, pp. 189-207.

Marmot M., Allen J., Bell R., Bloomer E., GoldBLATT P., 2012. WHO European review of social determinants of health and the health divide. The Lancet, vol. 380, no. 9846, pp. 1011-1029.

Meslé F., Vallin J., 2002. Mortality in Europe: The divergence between East and West. Population (English Edition, 2002-), vol. 57, no. 1, pp. 157-197.

MLÁDeK J., Čupérová K., 2010. Population processes and structures in the urban and rural spaces of Slovakia. European Countryside, vol. 2, no. 2, pp. 72-93.

MLÁDEK J., KáČEROVÁ M., 2008. Analysis of population ageing in Slovakia: Time and regional dimensions. Geografický časopis, vol. 60, no. 2, pp. 179-197.

Morris J.W. (ed.), 1972. World Geography. New York: McGraw-Hill Book Company.

Musil J., 1997. Potentials and limits of Prague's future in the context of long-term development. Czech Sociological Review, vol. 5, no. 1, pp. 23-38.

MykHnENKO V., TUROK I., 2007. Cities in transition: East European urban trajectories 1960-2005. Glasgow, Scotland: Centre for Public Policy for Regions, University of Glasgow. 
OECD, 2015. Ageing in cities. Paris: OECD Publishing, http://www.oecd.org/ [16 November 2016].

OlIVERI M. (ed.), 2015. Shaping ageing cities: 10 Europe case studies. Arup, Help Age International, Intel, Systematica.

OuŘEDníčEK M., 2007. Differential suburban development in Prague urban region. Geografiska Annaler: Series B, Human Geography, vol. 89, no. 2, pp. 111-125.

Popjaková D., Blažek M., 2015. Verification of counterurbanisation processes: Example of the České Budějovice region. Bulletin of Geography Socio-economic Series, vol. 27, no. 27, pp. 153-169.

PRB, 2015. 2015 World Population Data Sheet. http://www.prb.org/pdf15/2015-world-population-data-sheet_eng.pdf [14 November 2016].

PTÁČEK P., 1998. Suburbanizace - měnící se tvár zázemí velkoměst. Geografické rozhledy, vol. 7, no. 5, pp. 134-137.

RUOPPILA S., 2004. Processes of residential differentiation in socialist cities. European Journal of Spatial Development, no. 9, 24 pp.

SonIS M., 1981. Space and time in the geography of aging [in:] D.A. Griffith, R.D. Mackinnon (eds.), Dynamic Spatial Models: Proceedings of the NATO Advanced Study Institute on Dynamical Spatial Models, Alphen aan den Rijn: Sijthoff \& Noordhoff, pp. 132-156.

Soos G., IGNits G., 2003. Suburbanization and its consequences in the Budapest Metropolitan Area. Third EuroConference The European City in Transition, The City and the Region, Bauhaus-Universität Weimar, Germany, Supported by the European Commission.
SOSR, 1992-1997. Štatistická ročenka hlavného mesta SR Bratislavy 1991-1996. Statistical Yearbook of the Capital of the Slovak Republic Bratislava.

SOSR, 1993-2014. Pohyb obyvatel'stva v Slovenskej republike 1992-2013. The Population Change in the Slovak Republic ('Source Publication') in 1992-2013.

SOSR, 2015. Vekové zloženie - SR, oblasti, kraje, okresy, mesto, vidiek. Age Structure - SR, Areas, Regions, Districts, Urban, Rural.

ŠVEDA M., 2011. Suburbanizácia v zázemí Bratislavy z hladiska analýzy zmien krajinnej pokrývky. Geografický časopis, vol. 63, no. 2, pp. 155-173.

SZYMAŃSKA D., BiEGAŃSKA J., GIL A., 2009. Rural areas in Poland in the context of changes in population age structure in 1996, 2001 and 2006. Bulletin of Geography. Socio-economic Series, vol. 12, no. 12, pp. 91-107.

UNDATA, 2014. Standard country or area codes for statistical use. New York: Statistical Services Branch Statistics Division United Nations, http://data.un.org/[15 November 2016].

Vlahov D., Freudenberg N., Proletti F., Ompad D., Quinn A., Nandi V., GaleA S., 2007. Urban as a determinant of health. Journal of Urban Health, vol. 84, no. 1, pp. 16-26. 